\title{
Waste Footprint of Selected City Districts of Prague
}

\author{
By Dagmar Vološinová ${ }^{1}$, Libor Ansorge
}

\begin{abstract}
The growing population, thriving economy, rapid urbanisation significantly accelerate the generation of municipal waste. Tightening conditions for waste management are a challenge for all stakeholders to comply with the law and, at the same time, motivate them to reduce waste production. The knowledge of the biosphere's assimilation capacity can quantify the environmental impact of waste in an understandable and popular form to better understand the human need to assimilate the waste produced. Utilising the waste footprint indicator and anthropogenic emissions in the form of waste are converted into soil adsorption capacity. The article compares the waste footprints of different areas of the city of Prague. It quantifies the influence of living and waste services on the waste footprints of the capital inhabitants. This article also discusses the relationship of the waste footprint with other footprints and is intended to inform future debate on trace accounting.
\end{abstract}

Keywords: ecological footprint of waste generation ; waste management; municipal solid waste; sorted waste; collection waste; calculating analysis

\section{Introduction}

Cities and regions depend on resources and ecological services emerging from distant ecosystems. The prospertity of the urban population including the inhabitants of regions has been affected by both the quality and accessibility of these ecosystems. Managing the consumption of resources within a city or region, including the natural capital which supports these flows, is increasingly becoming a central concern of towns and areas that want to succeed. Urban infrastructure is an ever-evolving system and is affecting resource needs for decades to come. Reliable measures comparing the supply of natural resources with human demand are indispensable for managing resource consumption. They help to identify bottlenecks, set targets, monitor progress, and manage long-term sustainable policies. Disclosure of information on the state of the environment at several levels of the system (product, service, society, city, region, state, humanity) for various stakeholders (end consumers, businesses, politicians, academia) is an important area of sustainability. Ecological footprint, carbon footprint, water footprint, energy footprint, nitrogen footprint (Jiao et al., 2013), chemical footprint and material footprint are examples of footprint-based indicators that are commonly used to measure environmental emissions, resource use and other impacts. (Čuček et al., 2015) Each of these indicators publishes one layer of information on the effects of anthropogenic activities on the natural environment at different levels of the system, for other purposes, uses and users. For example, the ecological footprint (EF) measures the amount of biologically productive land and water needed to support population requirements and 
activities. Since its introduction by Rees and Wackernagel in the early 1990s (Wackernagel \& Rees, 1996), EF has been used in various studies and analyses across geographic areas, spatial scales, and time series. Analysts apply EF to understand and easily explain to the general public the context of meeting the needs of populations with a limited capacity of planetary ecosystems to provide a range of products and services. The EF confirms the definition of Ehrlich and Holdren (1971) about human impact on the environment. The definition can be expressed:

$\mathrm{I}=\mathrm{PAT}$

where $I$ is Impact, $P$ is Population, $A$ is Abundance and $T$ is Technology. In the definition of Ehrlich-Holdren (1971), impact (I) represents the ecological footprint of a population, which is a function of population size, and consumption (converted to land).

Because EF is relatively easy to calculate, understand and communicate to the public, EF is widely recognized as one of the most effective tools for assessing the sustainability of policies of states, regions, cities, municipalities and individual companies. The level of the economy, lifestyle and related waste production is one of the evaluated aspects of EF. For example, knowing which sectors generate the most waste can help design strategies to prevent and reduce waste at the source (Guan et al., 2019).

The ecological footprint of waste production (EWF) or the waste footprint means the measurement of biologically productive soil (energy soils, forest soils, pastures, built-up soils, etc.) to assimilate the generated waste.

On a macro scale, two views of waste products for specific areas are distinguished. This is part of production and consumption (Towa et al., 2020). The first part is responsible for the waste produced by the industry as a result of production activities. Final demand or waste generated by final consumption is accountable for the direct generation of garbage in part of consumption. However, the economic operator in the amount of consumption is ultimately responsible for the waste generated in the entire supply chain. This approach, also known as the waste footprint (WF) considers the final consumer accountable for the direct and indirect waste generation (Nakamura \& Kondo, 2009).

Many sophisticated methods based on input and output (IO) models of waste management analyzes have been introduced to determine EFW (Towa et al., 2020). IO models of waste management analyses have been applied in circular economics at the global and national levels. Still, not many of these studies have been performed for cities. For example, Fry et al. (2016) have developed a sub-national multi-regional waste supply-use framework and assesses waste production throughout the supply chain for Australian consumers. The impact of consumption activities in Tokyo was analyzed using the interregional waste input-output analysis model (Tsukui et al., 2015) and the Belgian regions of Brussels, Flanders and Wallonia were analyzed from the point of view of waste production using IO analysis called multi-regional hybrid IOT (Towa et al., 2021).

In the Czech Republic, IO tables are available at the regional level but do not exist in individual municipalities (Radvanský \& Lichner, 2021; Vltavská \& Sixta, 2017). Due to insufficient and inaccurate data to perform the above IO EWF analysis for three city districts of the capital city of Prague, we decided to use the Salequzzaman method (Salequzzaman et al., 2006). The aim was to find out what effect the produced municipal waste has and its management on the EWF of individual city districts. 


\section{Data and Methods}

\subsection{Wards studied}

The EWF calculation was performed in three city wards, which are served by the same collection system and the method of waste management (Vološinová et al., 2019). The main difference lies in urban development and the delivery distance to containers for sorted waste (CSW). Specifically, these were:

1. City centre - the centre of Prague (ward 1 - W1) consists of historical buildings. In this ward, municipal waste production is most affected by entities providing mainly accommodation and refreshment services. In the centre of Prague 1, CSWs are also placed in courtyards. The publicly accessible CSW network is the thinnest here. The population is 29,499 .

2. Housing development - the Horní Měchlupy housing estate (ward 2 - W2) consists of apartment buildings with district heating. Caloric fractions of municipal waste are not incinerated here. The CSW network is the densest of the three monitored types of buildings. Delivery distances of individual CSW are up to 100 meters and often overlap. The population is 37,950 .

3. Rural development - Újezd nad Lesy (ward 3 - W3) consists mainly of family houses surrounded by gardens and the associated increased production of biodegradable waste, usually not fed to livestock. Residents are motivated to compost. Thanks to gasification, the calorific fraction of municipal waste is not incinerated in this development either. The CSW network is the thinnest of the three types of buildings. The delivery distance is more significant than 100 meters, and there are no overlaps. The population is 10,352.

Due to the unavailability of accurate data on production and waste management in individual city districts, data from the Environmental Portal of the Capital City of Prague (MHMP, 2021) analyses of mixed waste monitored by the city wards in 2019 were used. The main methods of municipal waste management are the recycling of sorted components $(29 \%)$ and energy recovery $(60.48 \%)$, especially of mixed municipal waste.

Tab 1. Basic information on the production and management of municipal waste in Prague

\begin{tabular}{|l|c|}
\hline Characteristics & Value \\
\hline Municipal solid waste (MSW) production per year & $411,867.20 \mathrm{tonne}$ \\
\hline Municipal waste production per capita and year & $311.00 \mathrm{~kg}$ \\
\hline Amount of sorted waste and percentage of recycling: \\
\hline Paper & $26,148.94 \mathrm{~kg} ; 88 \%$ \\
\hline Plastic & $15,946.73 \mathrm{~kg} ; 50 \%$ \\
\hline Metal & $4,502.49 \mathrm{~kg} ; 57 \%$ \\
\hline Glass & $18,884.54 \mathrm{~kg} ; 79 \%$ \\
\hline Biowaste & $26,635.77 \mathrm{~kg} ; 95 \%$ \\
\hline Mixture MSW productin per year & $249,097.00 \mathrm{tons}$ \\
\hline
\end{tabular}




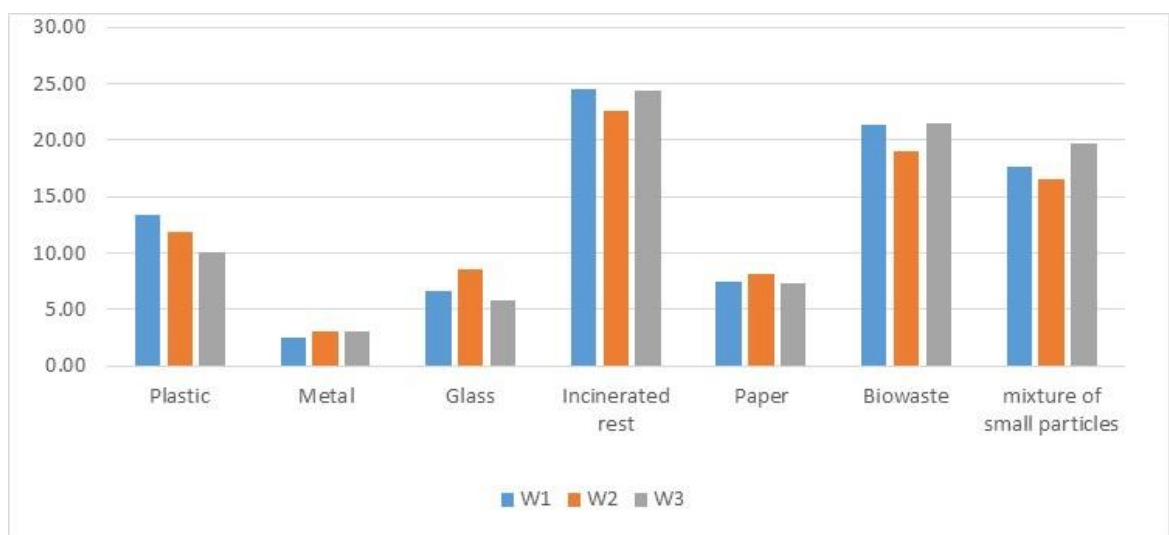

Fig 1. Composition of mixture MSW in monitored wards (in weight percent)

\subsection{Methodology of the study}

The methodology for assessing the EF (Salequzzaman et al., 2006) uses resource consumption and waste production and the category of soils for the assimilation of the waste produced.

Categorized land is used to estimate the EF.

Land use categories are summarized as:

1. Energy Land: The area of forest that would be needed to absorb $\mathrm{CO}_{2}$ emissions resulting from an individual's energy consumption.

2. Crop Land: The area of arable land needed to produce the crops that an individual consumes.

3. Pasture Land: The area of pastures needed to produce the necessary animal products.

4. Forest Land: Forest area needed for wood and paper production.

5. Sea Space: The area of sea needed for the production of sea fish and seafood.

6. Built Area: Land area needed for accommodation and infrastructure.

The EF of a community represents the sum of the soil requirements for six individual soil categories in the area per capita. Multiplying the data per capita by the population number of the selected area indicates the total EWF of the area. EF is expressed in terrestrial "area units" (in hectares), with each area unit corresponding to one hectare of the biologically productive area with average world productivity. For the calculation of the EWF, the generated waste is categorized into main groups such as paper, plastic, glass, metal, organic waste and combustible waste or non-recyclable waste, hygienically harmful.

The biologically productive land needed for waste production was calculated according to the equations below:

Paper - biologically productive soil is required for paper

$\mathrm{EL}=\mathrm{WEY} * \mathrm{EIP} *(\mathrm{PW} / \mathrm{WFP}) *(1-\% \mathrm{RP} * \% \mathrm{ERP})$

Where,

Energy land (EL) - energy soil expresses the amount of energy and $\mathrm{CO}_{2}$ emissions related to the life cycle of each material. $\mathrm{CO}_{2}$ data per tonne of material/product were used to calculate the energy footprint of the soil (i.e. the soil needed to capture carbon emissions). 0.27 hectares of world forest was used as a conversion factor, which is the average area of forest land needed to sequester 1 ton of $\mathrm{CO}_{2}$. One third was deducted from this amount, 
which represents the emissions absorbed by the oceans.

World energy yield (WEY); Energy intensity of paper (EIP); Amount of per capita paper waste per year (PW); Waste factor of paper (WFP); Percent of recycling of paper (RP); Percet of energy saved from recycling (ERP).

Forest land (FL) - data on energy inputs and carbon emissions are taken from LCA documents. Carbon dioxide was converted to energetic soil as described in equation (1). UNECE/FAO Forest Product Conversion Factors (n.d.) were used to obtain data on the amount of wood needed to produce different paper types. In addition, Global Footprint Network (Tools \& Resources - Global Footprint Network, n.d.) data were used to convert the equivalent weight of wood to the desired forest soil.

$\mathrm{FL}=\mathrm{WYW} * \mathrm{RWP} *(\mathrm{PW} / \mathrm{WFP}) *(1-\% \mathrm{RP} * \% \mathrm{ERP})$

Where, WYW - world average yield of round woods; RWP - ratio of round wood needed per unit papers; Percent of recycling of paper (RP); Percet of energy saved from recycling (ERP).

Built up Land (BL) - the built-up footprint is calculated based on land covered by human infrastructure - transport, housing, industrial buildings and water reservoirs. Built-up land can occupy what used to be arable land.

$\mathrm{BL}=\mathrm{EL} * \mathrm{BLFP} /(\mathrm{WFFAG}+\mathrm{WFFAW}) / \mathrm{BEFBL}$

Where, EL-energy land required for paper waste get from equation no. (1); BLFP - bulit up land footprint component of waste; WFFAG - world average fossil fuel area of goods; WFFAW-world average fossil fuel area of waste; BEFBL - primary biomass equivalence factor for bulit up area.

Plastic - biologically productive soil is required for plastic:

$\mathrm{EL}=\mathrm{WEY} * \mathrm{EIPl} *(\mathrm{PW} / \mathrm{WFPl}) *(1-\% \mathrm{RPl} * \% \mathrm{ERP})$

Where,

Energy land (EL); World energy yield (WEY); Energy intensity of plastic (EIPl); Amount of per capita plastic waste per year (PW); Waste factor of plastic (WFPl); Percent of recycling of plastic (RPl); Percet of energy saved from recycling (ERP).

Built up Land (BL)

$\mathrm{BL}=\mathrm{EL} * \mathrm{BLFP} /(\mathrm{WFFAG}+\mathrm{WFFAW}) / \mathrm{BEFBL}$

Where, EL-energy land required for plastic waste get from equation no. (4); BLFP - bulit up land footprint component of waste; WFFAG - world average fossil fuel area of goods; WFFAW-world average foddil fuel area of waste; BEFBL - primary biomass equivalence factor for bulit up area.

Glass - biologically productive soil is required for glass:

$\mathrm{EL}=\mathrm{WEY} * \mathrm{EIG} *(\mathrm{GW} / \mathrm{WFG}) *(1-\% \mathrm{RG} * \% \mathrm{ERP})$

Where,

Energy land (EL); World energy yield (WEY); Energy intensity of glass (EIG); Amount of per capita glass waste per year (GW); Waste factor of glass (WFG); Percent of recycling of glass (RG); Percet of energy saved from recycling (ERP).

Built up Land (BL)

$\mathrm{BL}=\mathrm{EL} * \mathrm{BLFP} /(\mathrm{WFFAG}+\mathrm{WFFAW}) / \mathrm{BEFBL}$

Where, EL - energy land required for glass waste get from equation no. (6); BLFP - bulit up land footprint component of waste; WFFAG - world average fossil fuel area of goods; 
WFFAW - world average foddil fuel area of waste; BEFBL - primary biomass equivalence factor for bulit up area.

Metal - a biologically productive soil is required for the metal:

$\mathrm{EL}=\mathrm{WEY} * \mathrm{EIM} *(\mathrm{MW} / \mathrm{WFM}) *(1-\% \mathrm{RM} * \% \mathrm{ERP})$

Where,

Energy land (EL); World energy yield (WEY); Energy intensity of metal (EIM); Amount of per capita metal waste per year (MW); Waste factor of metal (WFM); Percent of recycling of metal (RG); Percet of energy saved from recycling (ERP).

Built up Land (BL)

$\mathrm{BL}=\mathrm{EL} * \mathrm{BLFP} /(\mathrm{WFFAG}+\mathrm{WFFAW}) / \mathrm{BEFBL}$

Where, EL - energy land required for glass waste get from equation no. (8); BLFP - bulit up land footprint component of waste; WFFAG - world average fossil fuel area of goods; WFFAW - world average foddil fuel area of waste; BEFBL - primary biomass equivalence factor for bulit up area.

Biowaste - biologically productive soil is required for biowaste:

$\mathrm{EL}=\mathrm{WEY} * \mathrm{EIB} *\left(\frac{\mathrm{MW}}{\mathrm{WFB}}\right) *(1-\% \mathrm{RB} * \% \mathrm{ERP})$

Where,

Energy land (EL); World energy yield (WEY); Energy intensity of biowaste (EIB); Amount of per capita biowaste per year (BW); Waste factor of biowaste (WFB); Percent of recycling of biowaste (RB); Percet of energy saved from recycling (ERP).

For biowaste, it is necessary to calculate the amount of biogas produced by biowaste in the selected processing method. Calculate the production of energy from the resulting biogas. Calculate the percentage of energy recovered from biowaste. This data is fitted to the equation as ERP.

Calculation of biogas production:

$\mathrm{X}\left(\mathrm{m}^{3}\right)=$ amount of waste $(\mathrm{kg}) * \mathrm{TSC}(\%) *$ gas production rate per unit of waste $\left(\mathrm{m}^{3} / \mathrm{kg}\right)$ Calculation of produced energy:

$\mathrm{E} 1(\mathrm{~kJ})=\mathrm{X}\left(\mathrm{m}^{3}\right) *$ methane content in biogas $(\%) *$ calorific value of biogas $\left(\mathrm{kJ} / \mathrm{m}^{3}\right)$

Percentage of energy saved by processing biowaste (ERP):

$(\mathrm{E} 1 * 100) /$ amount of biowaste $=\mathrm{ERP}(\%)$

Built up Land (BL)

$\mathrm{BL}=\mathrm{EL} * \mathrm{BLFP} /(\mathrm{WFFAG}+\mathrm{WFFAW}) / \mathrm{BEFBL}$

Where, EL - energy land required for glass waste get from equation no. (10); BLFP - bulit up land footprint component of waste; WFFAG - world average fossil fuel area of goods; WFFAW - world average foddil fuel area of waste; BEFBL - primary biomass equivalence factor for bulit up area.

Incinerated rest - the energy part of municipal waste used was budgeted for individual commodities, and their energy gain was taken into account. At the same time, the use of metal that is separated from the slag and the use of slag together with fly ash as part of building materials were taken into account.

\section{Result}

The ecological footprint of the waste of the three monitored wards of Prague was 
calculated by the sum of the total biological productive soil for all types of waste that needs to be assimilated. see Table 2 .

Tab 2. Ecological footprint of municipal solid waste generation for three selected wards per capita (cap)

\begin{tabular}{|c|c|c|c|c|c|c|c|c|c|c|c|c|c|c|c|c|c|c|}
\hline \multirow{3}{*}{ 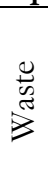 } & \multicolumn{9}{|c|}{ Land category } & \multirow{2}{*}{\multicolumn{3}{|c|}{$\begin{array}{l}\text { Sub-total } \\
\left(\mathrm{m}^{2} / \text { cap }\right)\end{array}$}} & \multirow{2}{*}{\multicolumn{3}{|c|}{$\begin{array}{l}\text { Total footprint } \\
\text { (Ha/cap) }\end{array}$}} & \multirow{2}{*}{\multicolumn{3}{|c|}{ Percentage }} \\
\hline & \multicolumn{3}{|c|}{$\begin{array}{c}\text { Energy land } \\
\left(\mathrm{m}^{2} / \mathrm{cap}\right)\end{array}$} & \multicolumn{3}{|c|}{$\begin{array}{c}\text { Forest land } \\
\left(\mathrm{m}^{2} / \mathrm{cap}\right)\end{array}$} & \multicolumn{3}{|c|}{$\begin{array}{l}\text { Build-up land } \\
\left(\mathrm{m}^{2} / \mathrm{cap}\right)\end{array}$} & & & & & & & & & \\
\hline & W1 & W2 & W3 & W1 & W2 & W3 & W1 & W2 & W3 & W1 & W2 & W3 & W1 & W2 & W3 & W1 & W2 & W3 \\
\hline $\begin{array}{c}\vec{\nu} \\
\text { जे } \\
\text { जे }\end{array}$ & $\stackrel{2}{\curvearrowright}$ & $\stackrel{5}{\infty}$ & $\stackrel{2}{r}$ & $\stackrel{0}{\longrightarrow}$ & 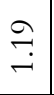 & $\stackrel{0}{\stackrel{\sim}{-}}$ & ڤે & $\stackrel{\sigma}{\delta}$ & ڤ. & $\underset{:}{\rightleftharpoons}$ & $\stackrel{\infty}{?}$ & $\stackrel{\infty}{0}$ & & & & $\exists$ & $\exists$ & $\exists$ \\
\hline 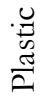 & $\begin{array}{l}\text { શิ } \\
\text { ¿ }\end{array}$ & $\frac{\infty}{\stackrel{\infty}{i}}$ & $\begin{array}{l}8 \\
\grave{1}\end{array}$ & & & & $\stackrel{+}{m}$ & テे & $\hat{m}$ & $\stackrel{m}{\ddot{n}}$ & $\stackrel{\stackrel{n}{n}}{\frac{n}{n}}$ & ñ? & & & & $m$ & $m$ & ñ \\
\hline 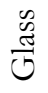 & $\begin{array}{l}\hat{\infty} \\
\dot{\sigma}\end{array}$ & $\begin{array}{l}\infty \\
\infty \\
\dot{\sigma}\end{array}$ & $\begin{array}{l}\infty \\
\dot{\sigma} \\
\dot{+}\end{array}$ & & & & ¿্. & $\stackrel{5}{0}$ & $\vec{\sigma}$ & $\begin{array}{l}\text { 市. } \\
\text { in }\end{array}$ & $\begin{array}{l}\infty \\
\text { in } \\
\text { in }\end{array}$ & 官 & & & & 0 & 0 & ○ \\
\hline 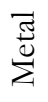 & $\begin{array}{l}\hat{\sigma} \\
\infty \\
\infty\end{array}$ & $\begin{array}{l}\stackrel{8}{0} \\
\text { ले }\end{array}$ & @i & & & & $\stackrel{\substack{\infty \\
+}}{\stackrel{+}{+}}$ & $\stackrel{\infty}{+\infty}$ & $\begin{array}{l}\infty \\
\infty \\
\stackrel{+}{+}\end{array}$ & $\begin{array}{l}\text { กิ } \\
\text { भ̊ }\end{array}$ & 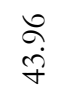 & $\stackrel{\infty}{\mathscr{q}}$ & 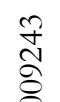 & $\begin{array}{l}\stackrel{0}{2} \\
\stackrel{2}{\delta}\end{array}$ & 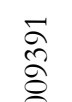 & ซ & 天े & F \\
\hline 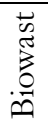 & $\stackrel{m}{\circ}$ & $\begin{array}{l}\infty \\
\stackrel{\infty}{n} \\
0\end{array}$ & @̆ & & & & $\stackrel{+}{\stackrel{+}{o}}$ & 今. & $\stackrel{m}{\circ}$ & $\stackrel{ヘ}{\overbrace{}}$ & : & $\stackrel{\leftrightarrow}{-}$ & & & & - & -1 & $\sim$ \\
\hline 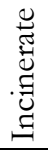 & $\stackrel{F}{r}$ & $\stackrel{?}{\stackrel{2}{\rightleftharpoons}}$ & 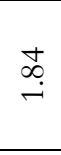 & & & & $\stackrel{\vec{\jmath}}{0}$ & กิ & $\stackrel{\overbrace{}}{0}$ & $\stackrel{\curvearrowright}{\overbrace{}}$ & $\stackrel{+}{\stackrel{\leftrightarrow}{-}}$ & $\stackrel{\widehat{o}}{\mathrm{i}}$ & & & & $N$ & $N$ & $N$ \\
\hline تే & $\frac{\ln }{\stackrel{\infty}{\infty}}$ & $\begin{array}{c}\text { กิ } \\
\infty\end{array}$ & $\begin{array}{l}\text { ț } \\
\stackrel{\infty}{\infty}\end{array}$ & $\begin{array}{l}\stackrel{0}{\rightleftharpoons} \\
\rightleftharpoons\end{array}$ & $\stackrel{\overbrace{}}{\rightleftarrows}$ & $\stackrel{\circ}{\stackrel{0}{\rightleftarrows}}$ & 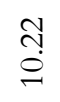 & 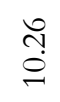 & $\begin{array}{l}\exists \\
\beth\end{array}$ & $\stackrel{\stackrel{?}{+}}{\stackrel{2}{\sigma}}$ & $\begin{array}{l}\stackrel{0}{\sigma} \\
\stackrel{2}{a}\end{array}$ & $\dot{a}$ & & & & $\underset{\ddots}{8}$ & $\underset{-}{8}$ & 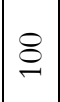 \\
\hline
\end{tabular}

Tab 3. Ecological footprint of municipal solid waste generation for three selected wards

\begin{tabular}{|l|c|c|c|c|c|c|}
\hline \multirow{2}{*}{ Waste components } & \multicolumn{3}{|c|}{ Land category } & Sub total \\
\cline { 2 - 6 } & $\begin{array}{c}\text { Energy land } \\
\left(\mathrm{m}^{2} / \mathrm{cap}\right)\end{array}$ & $\begin{array}{c}\text { Forest land } \\
\left(\mathrm{m}^{2} / \mathrm{cap}\right)\end{array}$ & $\begin{array}{c}\text { Built up land } \\
\left(\mathrm{m}^{2} / \mathrm{cap}\right)\end{array}$ & $\begin{array}{c}\text { Total } \\
\left(\mathrm{m}^{2} / \mathrm{cap}\right)\end{array}$ & $\begin{array}{c}\text { Percentage } \\
(\%)\end{array}$ \\
\hline Paper & 24.06 & 3.51 & 3.00 & 30.57 & & 11 \\
\hline Plastic & 81.57 & - & 10.18 & 91.75 & & 33 \\
\hline Glass & 16.61 & - & 1.83 & 18.44 & & 7 \\
\hline Metal & 116.88 & - & 14.58 & 131.46 & & 47 \\
\hline Biowaste & 2.51 & - & 1.36 & 3.87 & & 1 \\
\hline Incinerated rest & 5.28 & - & 0.66 & 5.94 & & 1 \\
\hline Total & 246.91 & 3.51 & 31.61 & 282.03 & 0.028 & 100 \\
\hline
\end{tabular}

The difference between the individual wards of Prague is not very significant due to the similar composition of the waste produced and the same method of waste collection and management. The largest EFW has a W3 with $93.91 \mathrm{~m}^{2} / \mathrm{cap}$ and a minor W1 with 92.43 
$\mathrm{m}^{2} /$ cap. The amount of biological waste produced has the most significant influence on the diversity of EFW individual sites (Table 3). However, its effect on EFW is only 1\% due to composting, which produces a minimum amount of methane. The components with the most significant impact on EFW include metals (47\%) and plastics (33\%), whose share is strongly influenced by the low recycling rate. Energy utilization of almost $61 \%$ of produced municipal waste needs the assimilation of only $5.94 \mathrm{~m}^{2} /$ cap and, like biowaste, represents only 1 percent of EFW.

\section{Discussion}

The same conversion factors as for Salequzzaman at al. (2006) were used to calculate the EFW due to the possibility of comparing the resulting EFWs of Prague and Bangladesh. Unlike Bangladesh, Prague does not have such significant differences between individual localities. Income groups are more mixed with each other. The amount and method of disposal for particular types of waste thus remain the compared.

In their work, Salequzzaman et al. stated that the highest EFW is food waste of $624 \mathrm{~m}^{2} / \mathrm{cap}$ due to almost no recycling. For paper the EFW is $152.85 \mathrm{~m}^{2} /$ cap, for metals $46.73 \mathrm{~m}^{2} / \mathrm{cap}$, for plastics $43.21 \mathrm{~m}^{2} / \mathrm{cap}$ and for glass $19.31 \mathrm{~m}^{2} /$ cap. In comparison with the results of EFW Prague, the need to support recycling activities at the same time as waste prevention can be confirmed. An eloquent example is EFW for metals. The EFW of metals in Prague averages $131.46 \mathrm{~m}^{2} / \mathrm{cap}$. It is caused by the increased popularity of aluminium beverage packaging and pet food packaging. The relatively sparse density of sorting containers causes low efficiency in the returning metals to the recycling process.

For this reason, there is a significant occurrence of this material in mixed municipal waste. Its recovery from combustible residues, unlike iron, is impossible. When comparing the EFW biowaste of Bangladesh and Prague, the difference of $620.13 \mathrm{~m}^{2} / \mathrm{cap}$ is due to Prague's extensive efforts to separate biowaste directly at the source and process it composting or in a biogas plant.

In contrast to Bangladesh, almost $57 \%$ of municipal waste is used for energy, and the EFW of the incinerated residue is $5.94 \mathrm{~m}^{2} / \mathrm{cap}$. The results show that in cities such as Prague, where most of its occupies are built up, the energy use of waste is currently the most efficient. However, the effort of all stakeholders should be to get as close as possible to the principles of circular economics. The obtained results only confirm the need to support recycling activities together with the prevention of waste generation.

The authors are aware that not including all waste in the life cycle chain of products and services in the calculation of EFW provides skewed results; however, even the figures presented to the general public can be an excellent educational tool. We believe that such a numerical expression of the impact of the waste produced and subsequently the method of its management can be a supporting tool for planning the development of technologies and the location of processing capacities and influencing the consumer behaviour of individuals. The simplicity of the analysis can support its dissemination even among stakeholders without knowledge of LCA analyses and be a tool for evaluating, planning or defending their activities. Last but not least, this data can be an incentive to monitor, collect, and make available data to create IO analyses. 


\section{Conclusion}

The paper aimed to provide an example of the ecological footprint of waste as a simple tool for evaluating the production and management of waste produced in particular wards. Application of the ecological footprint of waste was show on three different wards of Prague, the capital of the Czech Republick. Metal waste has the highest ecological footprint (47\% of the total ecological footprint of waste) followed by plastics (32-33\%). For greater clarity, a comparison was made with Bangladesh, where waste production is significantly different between individual wards than in Prague. The ecological footprint of waste demonstrates the importance of the chosen method of waste management, its impact on the environment. There is the potential to use easy calculation, understanding and communication for the general public.

\section{Acknowledgements}

The contribution was supported by the Institutional Funds for the Development of a Research Organization - TGM WRI, p. r. i. within the framework of an internal grant.

\section{References}

Čuček, L., Klemeš, J. J., \& Kravanja, Z. (2015). Chapter 5-Overview of environmental footprints. In J. J. Klemeš (Ed.), Assessing and Measuring Environmental Impact and Sustainability (pp. 131-193). Butterworth-Heinemann. https://doi.org/10.1016/B978-0-12-799968-5.00005-1

Ehrlich, P. R., \& Holdren, J. P. (1971). Impact of Population Growth. Science, 171(3977), 1212-1217. https://doi.org/10.1126/science.171.3977.1212

Forest Product Conversion Factors UNECE/FAO. (n.d.). Retrieved March 28, 2021, from https://unece.org/forests/publications/forest-product-conversion-factors

Fry, J., Lenzen, M., Giurco, D., \& Pauliuk, S. (2016). An Australian Multi-Regional Waste Supply-Use Framework. Journal of Industrial Ecology, 20(6), 1295-1305. https://doi.org/10.1111/jiec.12376

Guan, Y., Huang, G., Liu, L., Huang, C. Z., \& Zhai, M. (2019). Ecological network analysis for an industrial solid waste metabolism system. Environmental Pollution, 244, 279-287. https://doi.org/10.1016/j.envpol.2018.10.052

Jiao, W., Min, Q., Cheng, S., \& Li, W. (2013). The Waste Absorption Footprint (WAF): A methodological note on footprint calculations. Ecological Indicators, 34, 356-360. https://doi.org/10.1016/j.ecolind.2013.05.024

MHMP. (2021, March 9). Soubrnné informace o produkci a nakládáni s odpady v bl. M. Praze. Portál Životního Prostředí Hlavního Města Prahy. https://portalzp.praha.eu/jnp/cz/odpady/souhrnne_informace/index.html

Nakamura, S., \& Kondo, Y. (2009). Waste Input-Output Analysis: Concepts and Application to Industrial Ecology. Springer Science \& Business Media.

Radvanský, M., \& Lichner, I. (2021). An alternative approach to the construction of multi-regional inputoutput tables of the Czech Republic: Application of the CHARM method. Empirica. https://doi.org/10.1007/s10663-020-09490-6

Salequzzaman, M., Sultana, U. T., Iqbal, A., \& Hoque, M. A. (2006). Ecological footprint of waste generation: A sustainable tool for solid waste management of Khulna City Corporation of Bangladesh. Proc. International Conference on Complex Systems, 23-30. http://interjournal.org/manuscript_abstract.php?1207634194

Tools \& Resources_Global Footprint Network. (n.d.). Retrieved March 28, 2021, from https://www.footprintnetwork.org/resources/

Towa, E., Zeller, V., \& Achten, W. M. J. (2020). Input-output models and waste management analysis: A critical review. Journal of Cleaner Production, 249, 119359. https://doi.org/10.1016/j.jclepro.2019.119359

Towa, E., Zeller, V., Merciai, S., \& Achten, W. M. J. (2021). Regional waste footprint and waste treatments analysis. Waste Management, 124, 172-184. https://doi.org/10.1016/j.wasman.2021.02.011 
Tsukui, M., Kagawa, S., \& Kondo, Y. (2015). Measuring the waste footprint of cities in Japan: An interregional waste input-output analysis. Journal of Economic Structures, 4(1), 18. https://doi.org/10.1186/s40008015-0027-2

Vltavská, K., \& Sixta, J. (2017). Input-Output Tables for regions of the Czech Republic. Statistika, 97(2), 4-14. Scopus.

Vološinová, D., Kořínek, R., \& Makovcová, M. (2019). Monitoring odpadové obslužnosti pro tříděné složky komunálního odpadu na území Hlavního města Prahy. Vodohospodáršké Technicko-Ekonomické Informace, 61(6), 40. https://doi.org/10.46555/VTEI.2019.09.006

Wackernagel, M., \& Rees, W. E. (1996). Our ecological footprint: Reducing buman impact on the earth. New Society Publishers. 